\title{
Why Economic Sanctions on North Korea Fail to Work?
}

Chen Jiawen

\begin{abstract}
Imposed since 2006, the comprehensive multilateral economic sanctions against North Korea appear to have had little effect on the regime's pursuance of nuclear programs. Under the increasingly strict measures, Pyongyang has been demonstrating ever greater resolves to stick to its way of nuclear buildup. This study explores the reasons behind the failed economic sanctions from the international community. It argues that economic sanctions usually follow a two-step working mechanism, which is informed by multiple causal pathways. Accordingly, the effectiveness of sanctions is largely subject to the dynamic contexts of the target, senders and international community. Considering the causal logic from different aspects, this article identifies several obstacles. The most important one is that owing to North Korea's political structure and history, there is almost no constituency that may respond to the sanction pressure; on the contrary, economic sanctions seem to only increase domestic resistance against exogenous hostilities. In other words, it is not a regime that is likely to yield to coercive policies. Therefore, tougher
\end{abstract}

Chen Jiawen is Research Assistant at the Shanghai Institutes for International Studies (SIIS). She holds a BA in Art from Fudan University and an MSc in international relations and diplomacy from Leiden University. Her research interests include economic sanctions, conflict management and resolution, as well as the role of foreign direct investment in least developed nations. Her mailing address is: 195-15 Tianlin Road, Shanghai 200233, China. She can also be reached at jchen489@gmail.com.

(c) 2017 World Century Publishing Corporation and Shanghai Institutes for International Studies China Quarterly of International Strategic Studies, Vol. 3, No. 4, 513-534

DOI: $10.1142 / S 2377740017500300$ 
sanctions may only generate pressure, but they can hardly change North Korea's nuclear policy.

Keywords: Economic sanctions; North Korea; de-nuclearization; policy effectiveness; causal paths.

In 2006, the United Nations Security Council (UNSC) issued its first sanction-related resolution on the Democratic People's Republic of Korea (DPRK) in responding to a manifest threat to international peace and security posed by nuclear proliferation. However, the situation is yet to be improved after eight more rounds of sanctions. In a newly released statement, the Ministry of Foreign Affairs of the DPRK reiterated that "no one has the right to make a fuss about our test of hydrogen-bomb for intercontinental ballistic missile (ICBM) as it is a routine and indispensable process for the implementation of the strategic line that we have chosen for ourselves. ${ }^{1}$ North Korea's actions have been in line with this stance. Since the late North Korean leader Kim Jong-il announced the country's withdrawal from the Non-Proliferation Treaty (NPT) 14 years ago, North Korea has conducted six nuclear tests and more than 80 missile tests, among which there were two nuclear and 22 missile tests in 2016 alone. More recently, two successful launches of Hwasong-12 intermediate-range ballistic missiles that flew over Japan in September 2017 once again demonstrated Pyongyang's firm stance. Therefore, the existing economic sanction regime appears to have failed to bring about a change of policy, amidst the tensions building up in the region.

This article seeks to explain the specific reasons behind the ineffectiveness of economic sanctions in the case of the DPRK. Fundamentally, the key problem is that North Korea represents a type of country that poses substantial endogenous resistance to economic sanctions. If this problem is left unattended, even a fully implemented sanction regime would be highly unlikely to change North Korea's pursuance of nuclear weapons, let alone be able to achieve other policy agendas of the international community such as raising humanitarian awareness in the country. In short, policymakers of

1 "FM Spokesman Denounces US for Trying to Impose Additional Sanctions on DPRK," Korea Ryugilo Editorial Bureau, September 5, 2017, www.uriminzokkiri.com/index.php? lang $=$ eng\&ftype $=$ document $\&$ no $=5442 \&$ pagenum $=1$. 
the international community should note that in the case of North Korea, stepping up economic sanctions may remain insufficient to achieve their desired policy outcomes.

\section{A Theoretical Review of Economic Sanctions}

In 1919, U.S. President Woodrow Wilson raised the concept of economic sanctions when giving a speech in Indianapolis:

A nation that is boycotted is a nation that is in sight of surrender. Apply this economic, peaceful, silent, deadly remedy and there will be no need for force. It does not cost a life outside the nation boycotted but it brings a pressure upon the nation which, in my judgment, no modern nation could resist. ${ }^{2}$

Subsequently, these words "gave prominence to the collective use of economic sanctions as a means of deterring aggression." ${ }^{3}$

Economic sanctions are "the use or threat of use of economic capacity by one international actor, be it a state or international organization, or by a group of such actors, against another international actor, or group of actors." ${ }^{4}$ They are instruments of statecraft specifically geared to reinforce or change current behaviors, as well as to manipulate anticipated future ones. ${ }^{5}$ Typically, the policy aims at "seek[ing] to lower the aggregate

${ }^{2}$ Saul Kussiel Padover, Wilson's Ideals (Washington, D.C.: American Council on Public Affairs, 1942), p. 108.

${ }^{3}$ Gary Clyde Hufbauer, Kimberly Ann Elliott, and Jeffery Schott, Economic Sanctions Reconsidered (Washington, D.C.: Peterson Institute for International Economics, 2007).

${ }^{4}$ Sofia Heine-Ellison, "The Impact and Effectiveness of Multilateral Economic Sanctions: A Comparative Study," The International Journal of Human Rights, Vol. 5, No. 1 (2001), p. 83.

${ }^{5}$ David Singer, "Inter-Nation Influence: A Formal Model," American Political Science Review, Vol. 57, No. 2 (1963), pp. 420-430; Hufbauer et al., Economic Sanctions Reconsidered; T. Clifton Morgan and Navin A. Bapat, "Imposing Sanctions: States, Firms, and Economic Coercion," International Studies Review, Vol. 5, No. 4 (2003), pp. 65-79; David Allen Baldwin, Economic Statecraft (Princeton: Princeton University Press, 1985); and David Allen Baldwin, “Evaluating Economic Sanctions," International Security, Vol. 23, No. 2 (1998), pp. 189-195. 
(Imposed/Threat of using)
Economic Sanctions

Fig. 1. Economic Sanctions: A Two-step Working Mechanism.

Source: Created by author.

economic welfare of a target state by reducing international trade in order to coerce the target government to change its political behavior." ${ }^{\prime 6}$ It should be noted, however, that restriction on international trade is merely one of the measures, which also include arms embargoes, financial restrictions such as assets freeze, and restricting movement such as visa or travel bans. ${ }^{7}$

Yet many past cases have shown that economic isolation does not work well as tools of coercion in international relations. ${ }^{8}$ In fact, in "by far the most influential empirical study of the effectiveness of economic sanctions," ${ }^{9}$ Hufbauer, Schott, and Elliott point out that only 34 percent of the sanctions undertaken between 1914 and 1990 were effective, and the success rate is declining. ${ }^{10}$

How can economic sanctions be effective? Answering this question requires an understanding of the working mechanism of economic sanctions. According to the definition, this study regards economic sanctions as a two-step procedure (see Fig. 1): First, sanctions can exert certain pressure on the target. SecMost economic sanctions in history failed to bring about policy changes in target countries. ond, the pressure can coerce the target to change its policy. In terms of coercion,

${ }^{6}$ Robert A. Pape, "Why Economic Sanctions Do Not Work," International Security, Vol. 22, No. 2 (1997), p. 93.

${ }^{7}$ Service for Foreign Policy Instruments, "Sanctions," European Commissions, 2017, http://ec.europa.eu/dgs/fpi/what-we-do/sanctions_en.htm.

${ }^{8}$ Margaret P. Doxey, Economic Sanctions and International Enforcement, (Oxford: Oxford University Press, 1971); Robert Renwick, Economic Sanctions (Cambridge: Center for International Affairs, Harvard University, 1981).

${ }^{9}$ Richard W. Parker, "The Cost Effectiveness of Economic Sanctions," Law and Policy in International Business, Vol. 32 (2000), pp. 21-35.

${ }^{10}$ Hufbauer et al., Economic Sanctions Reconsidered. 
Wennmann explains that essentially economic sanctions are not "soft" policy acts but coercive ones, ${ }^{11}$ which are "designed to cause damage to the targeted party, in order to force it to undertake, or prevent it from undertaking, certain behavior." ${ }^{12}$ It is important to note, however, that the level of pressure does not necessarily determine the outcome of the second step. As Parker finds out, in some cases, without actual harm, the threat alone is sufficient to achieve the desired results. ${ }^{13}$ One assumption is that the target perceives certain pressure from, for instance, diplomatic relations and decides to change its behavior accordingly. On the other hand, the highest level of economic coercion does not guarantee the target's concessions. For the target may find its way to diminish the perceived pressure without making compromise, or the target does not even perceive the actual pressure that the senders aim to pose with the sanctions. In this regard, the target's perception of "pressure" is the determining factor in the first step, whereas the target's reaction upon the calculation of its capability of dealing with the "pressure" plays a crucial role in the second step. Importantly, both steps have to be fulfilled in order to produce positive policy outcomes. In short, it is the target, rather than the senders, that directly alter the former's (policy) behaviors.

The two-step procedure raises the question as to whether there are any particular sets of factors that can be associated with successfully perceived pressure and subsequent policy. In a review of UN sanction regimes, De Jonge Oudraat highlights "the economic and political characteristics of the target," which can both enhance and weaken the impact of sanctions. ${ }^{14}$ For instance, "market economies are generally more vulnerable to economic sanctions than centrally planned ones," ${ }^{\prime 15}$ as they allow sanctions to have a greater likelihood of success in exerting economic suffering, which can in turn place certain objective pressure on the target. However, an expected high level of objective pressure may still not be delivered to the target, as

${ }^{11}$ Achim Wennmann, The Political Economy of Peacemaking (London: Routledge, 2011).

${ }^{12}$ Konstanty Gebert, Shooting in the Dark? EU Sanctions Policies (Brussels: European Council on Foreign Relations, 2013).

${ }^{13}$ Parker, "The Cost Effectiveness of Economic Sanctions."

${ }^{14}$ Chantal De Jonge Oudraat, "Making Economic Sanctions Work," Survival, Vol. 42, No. 3 (2000), pp. 105-128.

${ }^{15} \mathrm{Ibid}$, p. 115. 
the pressure could be offset by the impact of contextual factors such as low global commodity prices and great sanction costs to the senders. ${ }^{16}$ In theory, trade restrictions imposed by the sender will be unaffordable for countries that rely heavily on exports to the sender's market, yet they may be less efficient if the country can balance trade loss with, for instance, a new source of income derived from global market demands. Therefore, both the target's and senders' characteristics as well as other seemingly irrelevant contextual conditions can be powerful catalysts or obstacles. With the involvement of these factors, sanction episodes become essentially a contextual phenomenon. ${ }^{17}$ In other words, while the two-step working mechanism seems to show a straightforward linear relation between economic sanctions and policy goals, both steps are composed of numerous non-linear paths (see Fig. 2). Thus, conditions under which economic sanctions follow the two-step procedure are different case by case. Likewise, the sources of "pressure" vary significantly among different targets. This fact in part justifies the use of the case study approach in this discipline.

From this stance, many studies that focus on figuring out the causal relations between economic sanctions and policy outcomes may only

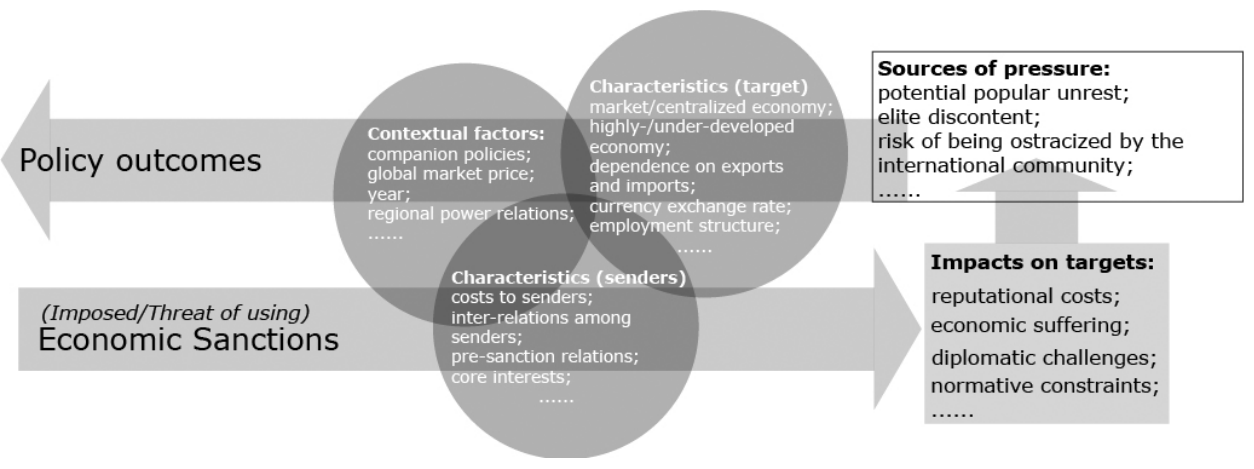

Fig. 2. Multiple Causal Pathways of Economic Sanctions.

Source: Created by author.

${ }^{16}$ Jaleh Dashti-Gibson, Patricia Davis and Benjamin Radcliff, "On the Determinants of the Success of Economic Sanctions: An Empirical Analysis," American Journal of Political Science, Vol. 41, No. 2 (1997), pp. 608-618.

${ }^{17}$ Diana Richards, ed., Political Complexity: Nonlinear Models of Politics (Ann Arbor: University of Michigan Press, 2000), p. 270. 
emphasize one particular path. The most commonly considered route is that economic costs derived from trade restrictions will result in "cost[s] on people's livelihood[s],"18 which can in turn trigger "public anger and politically significant protest," thereby "lead[ing] to changes in the behavior of trouble-making élites, or their removal from power."19 However, just as Drezner argues, while the theory is both parsimonious and elegant, "it relies on only one causal mechanism through which sanctions lead to policy concessions. ${ }^{20}$ Hakimian further questions whether this path stands up to scrutiny, as the uprisings in the Middle East in recent years do not always comply with the logic. ${ }^{21}$

\section{The effectiveness of}

economic sanctions

depends on a

multitude of

interrelated factors.
Therefore, in examining the case of North Korea, this article takes into account multiple causal pathways that rest on different theoretical perspectives. Yet, rather than identifying contributing factors that may lead to positive policy outcomes, the following analyses serve to inform several notable undermining factors that sustain the DPRK's pursuance of nuclear weapon programs.

\section{Economic Sanctions on North Korea: Wrong Targets and the Income Myth}

Any attempt to analyze economic sanctions should first reach the two-fold goals: "defining the boundaries of episodes and establishing the criteria

\footnotetext{
${ }^{18}$ Stephan Haggard and Marcus Noland, Hard Target: Sanctions, Inducements, and the Case of North Korea (Redwood City: Stanford University Press, 2017), p. 3.

${ }^{19}$ De Jonge Oudraat, "Making Economic Sanctions Work," p. 105.

${ }^{20}$ Daniel W. Drezner, "An Analytically Eclectic Approach to Sanctions and Nonproliferation," in Etel Solingen, ed., Sanctions, Statecraft, and Nuclear Proliferation (Cambridge: Cambridge University Press, 2012), p. 155.

${ }^{21}$ Toni Johnson and Hassan Hakimian, “How Sanctions Affect Iran's Economy," Interview Transcript, Council on Foreign Relations, 2012, https://www.cfr.org/interview/howsanctions-affect-irans-economy.
} 
of success." ${ }^{22}$ In order to understand the ineffectiveness of economic sanctions on North Korea, it is thus necessary to identify the senders, measures and aims.

The current sanction episode on the DPRK is both multilateral and comprehensive. It involves several notable senders: the United Nations (UN), the United States, and the European Union (EU). They seek to achieve a variety of goals with different forms of measures, targeting both the state and marked individuals.

Leading the current sanction regime, the UN Security Council underscores that the use of sanctions is "to ensure international peace and security, and ensure lasting stability in north-east Asia at large and to resolve the [proliferation of nuclear weapons] through peaceful, diplomatic and political means." ${ }^{23}$ Similarly, two principles that China firmly upholds when engaging the Korean Peninsula are "under no circumstances [sh]ould the Peninsula be nuclearized" and "no military solution to the [North Korea] issue." ${ }^{24}$ Regarding the EU, the scope of objectives is expanded, including not only "supporting a lasting reduction of tensions on the Korean Peninsula and in the region and the upholding of the international non-proliferation regime," but also "the improvement of the situation of human rights in the DPRK." ${ }^{25}$ Still, similar to both the UN and China, the EU highlights that dialogue and engagement with the DPRK "are necessary to achieving a positive resolution of all issues of concern." ${ }^{26}$

In comparison, some American policy analysts are suspicious of the feasibility of dialogues. For instance, in a recent congressional testimony, Anthony Ruggiero, a senior fellow at the Foundation for Defense of Democracies, pointed out that North Korean leader Kim Jong-un would

${ }^{22}$ Richard W. Parker, “The Cost Effectiveness of Economic Sanctions,” p. 33.

${ }^{23}$ Adopted by the Security Council at its 8042nd meeting, on September 11, 2017, UN Doc. S/RES/2375 (2017), https://www.un.org/sc/suborg/en/s/res/2375-\%282017\%29.

24"Wang Yi Talks about Principles China Upholds in Dealing with the Korean Peninsula Nuclear Issue," Chinese Foreign Ministry, February 13, 2016, http://www.fmprc.gov.cn/ mfa_eng/zxxx_662805/t1340527.shtml.

${ }^{25}$ EEAS, “Fact Sheet DPRK," European Unions, April 7, 2017, http://eeas.europa.eu/sites/ eeas/files/20170407_eeas_eu-dprk_fact_sheet.pdf.

${ }^{26}$ Ibid, p. 2. 
view negotiations "merely as one step toward his goal of recognition of North Korea as a state with nuclear weapons." 27 Having witnessed an increasingly aggressive attitude of Pyongyang, some American officials went further by suggesting preemptive military actions as an option. Notably, the Trump administration has hinted at the possibility of using armed forces, stating that "all options are on the table," including military ones. ${ }^{28}$ Meanwhile, Nikki Haley, U.S. ambassador to the United Nations, also addressed in the UN that Kim is "begging for war." ${ }^{29}$ Conversely, many experts do not regard preemptive strikes on North Korea as a viable option. Scholars such as Stephan Haggard criticizes this policy trend, saying that most commentators "read the first $95 \%$ of the resolution and forgot the last bit that the purpose of sanctions was to return to negotiations." ${ }^{30}$

Nevertheless, there is one clear concern shared by all senders: the proliferation of nuclear- and ballistic-related weapon programs. Even the U.S. government has described the policy intention as "deal[ing] with the threat...constituted by the existence and risk of the proliferation of weapons-usable fissile material on the Korean Peninsula." ${ }^{31}$ Therefore, it is believed that the senders' policy aim is still for North Korea to abandon its development of nuclear- and missile-related weapon programs (see Fig. 3). Reopening negotiation definitely remains as a policy goal, yet unlike

${ }^{27}$ Anthony Ruggiero, "A Legislative Proposal to Impede North Korea's Access to Finance," Testimony at the Monetary Policy and Trade Subcommittee of the U.S. House Committee on Financial Services, July 19, 2017, http://www.defenddemocracy.org/content/ uploads/documents/Anthony_Ruggiero_Testimony_HFSC.pdf.

${ }^{28}$ Albert Eleanor, "What to Know About the Sanctions on North Korea," Council on Foreign Relations, November 27, 2017, https://www.cfr.org/backgrounder/what-knowabout-sanctions-north-korea.

${ }^{29}$ Jeremy Herb, Joshua Berlinger, and Taehoon Lee, “Haley: Kim Jong Un 'Begging for War,"' CNN, September 5, 2017, www.cnn.com/2017/09/04/politics/haley-north-korea-united-nations/index.html.

${ }^{30}$ Haggard and Noland, Hard Target: Sanctions, Inducements, and the Case of North Korea, p. 11.

${ }^{31}$ Office of Foreign Assets Control, "North Korea Sanctions Program," Department of the Treasury, November 2, 2016, http://www.treasury.gov/resource-center/sanctions/Programs/Documents/nkorea.pdf. 


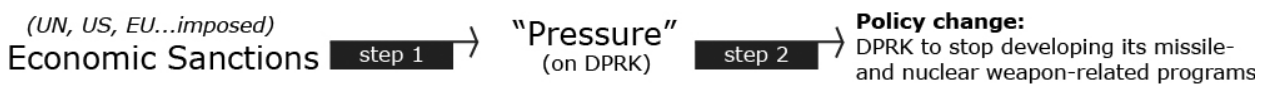

Fig. 3. Economic Sanctions on North Korea.

Source: Created by author.

de-nuclearization, it is not accounted for a necessary condition for lifting the sanctions.

According to the provision of UNSC resolutions and sender governments' official documents, ${ }^{32}$ key measures of the economic sanctions on the DPRK include:

(1) Embargoes on luxury goods as well as any material, arms, technology, energy (petroleum, natural gas and crude oil), service, and transportation linked to nuclear and missile programs;

(2) Limited bilateral diplomatic missions and consular posts;

(3) Financial restraints that include, for instance, limited financial services and prohibiting joint ventures or cooperative entities;

(4) Travel ban and asset freeze on designated individuals;

(5) Additional measures recently imposed by the United States and the EU: export, import and investment restrictions; and a comprehensive blocking of the Government of North Korea and the Workers' Party of Korea.

Given the measures of economic sanctions, it is apparent that one potential causal path of economic sanctions is to seek to weaken North Korea's capabilities to materialize the weapon programs (see Fig. 4). Notably, the needed materials, technological assistance and personnel are highlighted as the focus of restrictions. In this sense, sanctions are expected to deny North Korea's access to the actual material basis of the programs, which, in turn, can form a significant level of sensible pressure should North Korea continue the nuclear buildup, and even force them to abandon the plan.

${ }^{32}$ Ibid; “Security Council Committee Established Pursuant to Resolution 1718 (2006)," United Nations Security Council Subsidiary Organs, https://www.un.org/sc/suborg/en/ sanctions/1718; “Fact Sheet — EU-Democratic People's Republic of Korea (DPRK) Relations," EEAS https://eeas.europa.eu/sites/eeas/files/eu_dprk_factsheet_0.pdf. 


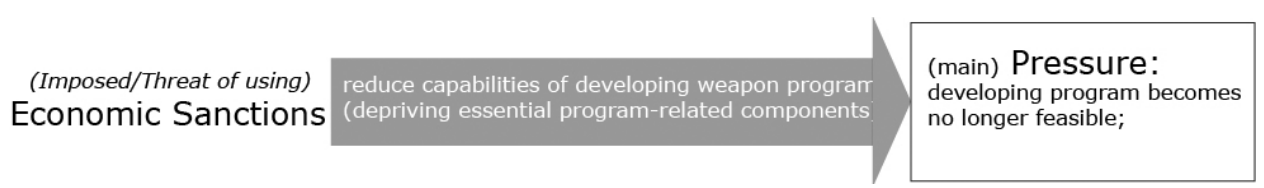

Fig. 4. Potential Causal Path: Curbing Nuclear Capabilities.

Source: Created by author.

However, if curbing actual capabilities is seen as the goal, the targets of the previously-mentioned measures are clearly misplaced.

Indeed, limited access to relevant materials, arms and technology constitutes a challenge for North Korea's nuclear plan. However, as long as Pyongyang has sufficient government revenue, ${ }^{33}$ it can continue to support transfer of physical and non-physical program-related assets. This can be done through underground economic networks such as the black market and smuggling, which are widespread in the era of globalization and difficult to regulate. In fact, the UN has noted such facts. For instance, as shown in the civil wars in some countries, since they are usually "fought with small arms and light weapons... [while] the international trade in weapons such as these is difficult to regulate and verify, especially since much of it is conducted on the black market," there have been a decreased use of arms embargo by the UN in stopping internal warfare. ${ }^{34}$

Thus, rather than the needed goods, the target of measures should be the key sources of Pyongyang's government income, which is the prerequisite that makes weapon programs realizable. However, "prior to 2016, U.S. and international sanctions against North Korea were primarily designed to target specific entities. . .rather than creating broader pressure on the country's economy." ${ }^{35}$ Only recently were some of the sanctions

\footnotetext{
${ }^{33}$ Whereas government revenue in most cases refers to official statistics, this article defines the term as all possible income that the DPRK government can obtain, regardless of its sources.

${ }^{34}$ De Jonge Oudraat, "Making Economic Sanctions Work."

${ }^{35}$ Edward Fishman, Peter Harrell, and Elizabeth Rosenberg, "A Blueprint for New Sanctions on North Korea," Center for a New American Security, July 24, 2017, https://s3.amazonaws.com/files.cnas.org/documents/CNASReport-NK-Final.pdf?mtime= 20170724120612.
} 
initiated by the United States and EU expanded to apply more comprehensive measures targeting the whole North Korean economy.

However, one key issue needs to be clarified before determining if economic sanctions can impose significant costs on North Korea's revenue: what constitutes income? As noted by Frank, there are a "few regular sources of information" showing the domestic economic situation, and these "should be taken with a good grain of salt." ${ }^{\prime 36}$ Due to the inaccessibility of macroeconomic data, the answer is never

Due to lack of data transparency, economic sanctions on North Korea have been wrongly targeted. articulated. Accordingly, this article can only outline a rough picture of North Korea's economy with some (arguably) reliable macroeconomic data. The picture serves only to estimate the result of economic restraints rather than confirm the sources of the DPRK's revenue.

According to the Bank of Korea, despite the economic sanctions, North Korea's GDP registered a 3.9 percent growth in 2016 (see Fig. 5). ${ }^{37}$ Meanwhile, South Korean government-affiliated Korea Trade-Investment Promotion Agency (KOTRA) estimated that the North Korean state budget grew between 4 to 6 percent in 2016. Moreover, KOTRA also revealed that North Korean trade volume (exports plus imports) has been expanding, showing a 5 percent growth over 2016 and reached US $\$ 6.5$ billion (see Fig. 6). ${ }^{38}$

Given the three sets of macroeconomic data outlined, it seems North Korea's whole economy is far from being pressured (if not actually flourishing). In other words, economic losses appear to be much less than expected. In particular, North Korea's trade with the outside world has

${ }^{36}$ Ruediger Frank, “North Korea's Foreign Trade,” 38 North, October 22, 2015, www.38north.org/2015/10/rfrank102215/.

${ }^{37}$ Rosamond Hutt, “North Korea's Economy Grew Nearly 4\% Last Year — Despite Sanctions," World Economic Forum, August, 2017, http://www.weforum.org/agenda/2017/ 08/north-korea-s-economic-growth-was-at-a-17-year-high-in-2016-so-which-countries-wasit-trading-with/.

38“2016년 북한의 대외무역 동향 (North Korea's Foreign Trade 2016),” Korea TradeInvestment Promotion Agency, http://news.kotra.or.kr/common/extra/kotranews/globalBbs/ 249/fileDownLoad/47252.do. 


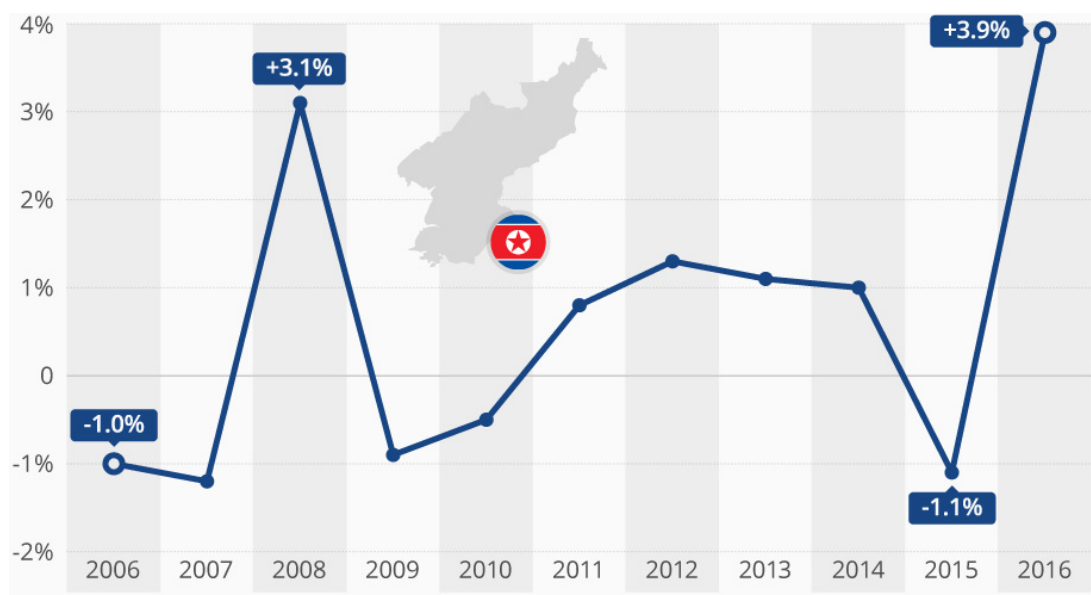

Fig. 5. Estimated Year-On-Year GDP Growth of North Korea.

Source: Bank of Korea.

[표 II-1] 북한의 연도별 대외무역 추이

in 1,000 USD

\begin{tabular}{|c|c|c|c|c|}
\hline & 구분 & 2014년 & 2015년 & 2016년 \\
\hline Exports & 수 출 & $3,164,650$ & $2,696,538$ & $2,820,914(\uparrow 4.6 \%)$ \\
\hline Imports & 수입 & $4,446,231$ & $3,555,278$ & $3,725,700(\uparrow 4.8 \%)$ \\
\hline Total & 합계 & $7,610,881$ & $6,251,816$ & $6,546,614(\uparrow 4.7 \%)$ \\
\hline Trade balance & 무역수지 & $-1,281,581$ & -858.740 & $-904.786(15.4 \%)$ \\
\hline
\end{tabular}

"( )안은 전년대비 증감률, 자료원 : KOTRA

[그림 II-1] 북한의 연도별 수출입 추이

in millionUSD

(단위 : \$ 백만)

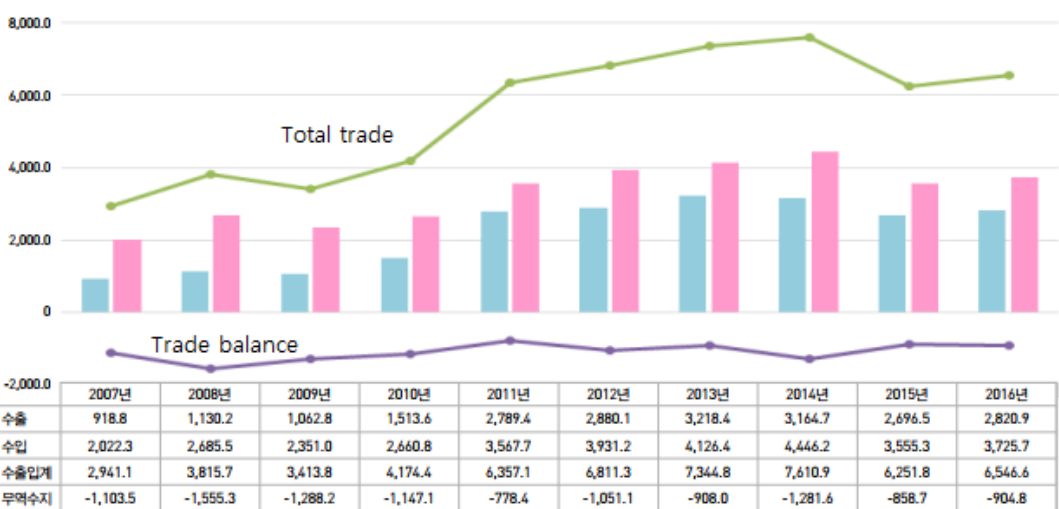

자료원 : KOTRA Source: KOTRA

Fig. 6. North Korea's Trade by Year.

Source: KOTRA. 
steadily increased during sanctions. Since it is widely assumed that exports are the mainstay of North Korea's revenue (Haggard further remarks that over the past ten years, North Korea's export economy has depended increasingly on raw materials, which has turned it into a typical rentier state), ${ }^{39}$ many argue that sanctions evasion should be accounted for the main reason of the sanction failure. As a result, North Korea's trading partners, in particular China, are frequently being accused of undermining the effectiveness of the sanction regime. They are criticized as "black knights," 40 or spoilers, "who helped replace target states' lost trade and aid with their own," ${ }^{41}$ thereby undermining sanctions.

However, this judgment is based on one key precondition, that is, trade constitutes an irreplaceable and indispensable portion of the DPRK's funding. As one Chinese old saying goes, sufficient knowledge of you and me leads to victory (知已知彼, 百战不殆). However, as previously noted, the DPRK hardly disclosed any reliable macroeconomic data. Since economic sanctions are specifically geared to cause damage to North Korea's economy, it is questionable whether the senders can still achieve this goal without comprehensive knowledge of the domestic political economy in North Korea (see Fig. 7).

In fact, hacking activities intended to steal money from financial institutions, including the World Bank and national banks, have been increasingly cited as a potential alternative source of North Korean income, in addition to the black market and smuggling. ${ }^{42}$ If there are more unreported financial dealings as such,

North Korea could have exploited many hidden channels to sustain its international income. then a complete ban on trade is unlikely to accomplish the task of cutting down North

${ }^{39}$ Haggard and Noland, Hard Target: Sanctions, Inducements, and the Case of North Korea, p. 2.

${ }^{40}$ Hufbauer et al., Economic Sanctions Reconsidered.

${ }^{41}$ Elizabeth S. Rogers, "Using Economic Sanctions to Prevent Deadly Conflict," CSIA Discussion Paper 96-02 (Cambridge: Kennedy School of Government, Harvard University, 1996).

${ }^{42}$ See, for example, Nicole Perlroth and Michael Corkery, "North Korea Linked to Digital Attacks on Global Banks," The New York Times, May 26, 2016, www.nytimes.com/ 2016/05/27/business/dealbook/north-korea-linked-to-digital-thefts-from-global-banks.html. 


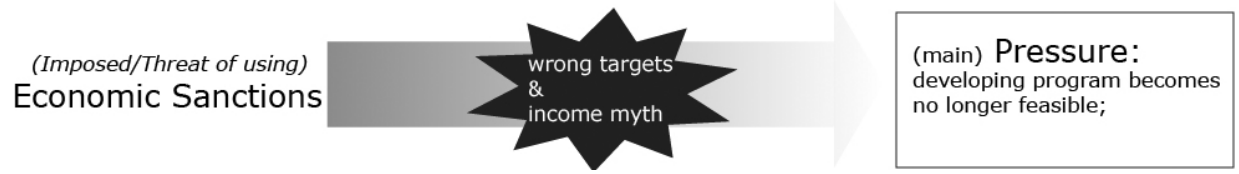

Fig. 7. Obstacle in the Potential Causal Path: Lack of Data. Source: Created by author.

Korea's funding for weapon programs. This represents a general flaw embedded in the design of economic sanctions, as they remain focused on conventional economic and financial access, disregarding the fact that the globalization process is putting forward more advanced funding channels, alongside a complex global financial network. As sanctions are essentially inconsistent with global economy under a liberal order, they are expected to face more similar challenges as illustrated in the North Korea case.

\section{Key Barriers to Economic Sanctions on North Korea}

In respect to the current trend of the North Korea sanction regime regarding pressuring China for tougher sanctions, this study identifies another possible pressure source apart from seeking economic losses. As mentioned in Drezner's study, one causal path is that "multilateral sanctions signal normative disapproval by the rest of the international community; the target government alters its policies so as to avoid being ostracized." 43 Therefore, well-aligned sanction regimes (especially with the joining of key allies into sanctioning countries) are expected to produce normative isolation.

Nevertheless, would pressing for stricter enforcement of UN multilateral sanctions (particularly by China) be effective in this regard? Existing studies suggest that international cooperation was neither a sufficient nor a necessary condition for the success of sanction episodes. ${ }^{44}$ Of course, in applying the two-step procedure, if the costs derived from normative

${ }^{43}$ Drezner, "An Analytically Eclectic Approach to Sanctions and Nonproliferation," p. 164.

${ }^{44}$ Daniel W. Drezner, The Sanctions Paradox: Economic Statecraft and International Relations (Cambridge: Cambridge University Press, 1999); Hufbauer et al., Economic Sanctions Reconsidered; William H. Kaempfer and Anton D. Lowenberg, "Unilateral versus Multilateral International Sanctions: A Public Choice Perspective," International Studies Quarterly, Vol. 43, No. 1 (1999), pp. 37-58. 


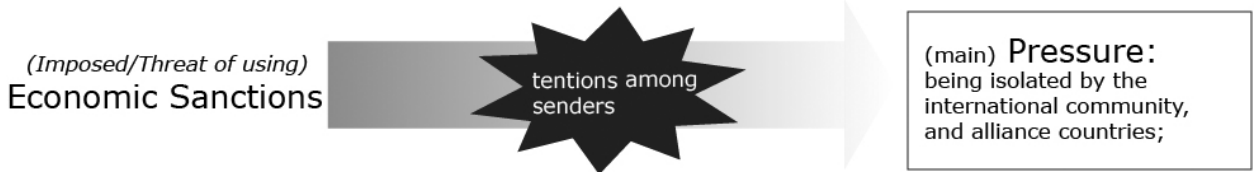

Fig. 8. Obstacle in the Potential Causal Path: Disagreement Among Senders. Source: Created by author.

constraints significantly outweigh the benefits from target policies, it is indeed possible for the sanctioned country to consider concession. Yet this condition can hardly be fulfilled in the case of North Korea.

Since international cooperation is not a determining factor, seeking a tougher sanction regime through the threat of using secondary sanctions on China is even more problematic. According to Shambaugh, the United States has had limited success in enforcing its export control regime using secondary sanctions directed against foreign firms. ${ }^{45}$ In fact, the Iranian case has taught us that such sanctions are easily skirted. ${ }^{46}$ Furthermore, as Haggard states, "the more tension there is between senders, the less likelihood there is that North Korea's going to give up on its nuclear weapons program" $^{47}$ (see Fig. 8).

Of course, if trade volume shrinks and China puts forward stricter sanctions, it will more or less add to the current economic losses and normative distress of the DPRK, which may in turn generate a significant level of pressure. However, as realities have shown, even a maximum level of pressure (regardless of its sources) seems unlikely to bring about a denuclearization policy by North Korea. Similar to what De Jonge Oudraat explained, "comprehensive sanctions may have a significant impact on a target's economy but this does not necessarily translate into changes in

${ }^{45}$ George E. Shambaugh, States, Firms, and Power: Successful Sanctions in United States Foreign Policy (Albany: State University of New York Press, 1999).

${ }^{46}$ Alon Levkowitz, "North Korea: Sanctions Are Not Enough," Begin-Sadat Center for Strategic Studies, August 4, 2017, https://besacenter.org/perspectives-papers/north-koreasanctions/.

${ }^{47}$ Haggard and Noland, Hard Target: Sanctions, Inducements, and the Case of North Korea, p. 4. 
political behavior; on the contrary, they may solidify the target's positions." ${ }^{\prime 4}$ In the context of North Korea, the failure of sanctions is both due to the centralized political system and to the high domestic resistance of North Koreans that is partly caused by the past sanctions.

As widely acknowledged, North Korea is characterized by a highly centralized power structure that is built on family dynastic succession. ${ }^{49}$ Yet the Kim family is not necessarily the only policymaker. ${ }^{50}$ Instead, the "designated individuals" noted in the sanctioning list and other privileged elites (songbun) — the high-ranking military officers, Workers' Party officials, senior bureaucrats, business leaders and diplomats who prosper because of their backgrounds and personal affiliations ${ }^{51}$ - may hold much decisive power that is not fully appreciated.

Sanctions targeting North Korean elites are mostly turned into suffering of the ordinary people.
Under the authoritarian ruling class, one notable feature of North Korea's social structure is the public distribution system (PDS). Though anecdotal information suggests that market distribution has been increasingly replacing the role of the PDS, ${ }^{52}$ there is little doubt that North Korea remains a non-market economy. Due to the PDS, alongside the strict control over many other

${ }^{48}$ De Jonge Oudraat, “Making Economic Sanctions Work,” p. 118.

${ }^{49}$ Victor Cha and Lee Ji-Young, "Politics of North Korea," Oxford Bibliographies, 2017, www.oxfordbibliographies.com/view/document/obo-9780199756223/obo-97801997562230109.xml.

${ }^{50}$ Hazel Smith, "North Korea: Intra-elite Conflict and the Relevance for Global Security," Center for Strategic and International Studies, May 24, 2017, https://www.csis.org/ search?search_api_views_fulltext=North $\% 20$ Korea $\% 3 \mathrm{~A} \% 20$ Intra-elite $\% 20$ Conflict $\% 20$ and $\%$ 20the\%20Relevance\%20for\%20Global\%20Security.

${ }^{51}$ Michael Pembroke, "The Privileged Elite of North Korea Live A Charmed Life," Sydney Morning Herald, May 3 2017, http://www.smh.com.au/comment/the-privileged-eliteof-north-korea-live-a-charmed-life-20170430-gvvt40.html.

${ }^{52}$ Beyond Parallel, “Meager Rations, Banned Markets, and Growing Anger Toward Government," Center for Strategic and International Studies, October 3, 2016, https:// beyondparallel.csis.org/view-inside-north-korea-meager-rations-banned-markets-andgrowing-anger-toward-govt/. 
social units, privileged residents' needs are certainly prioritized. ${ }^{53}$ In a recent survey, in responding to the question "does the public distribution system provide you with what you want for a good life?," none of the 36 respondents answered "yes." ${ }^{54}$ In this way, it would appear that the pressure derived from economic losses is being effectively passed on to civilians. In other words, the sanctions that target elite individuals are essentially being turned into suffering of the innocent masses.

Indeed, while the elite class has been so far "largely insulated from economic hardship and the effect of sanctions," ${ }^{\prime 55}$ the cost to people's livelihoods is real, which in essence fulfills one potential source of pressure (see Fig. 9). Yet, in order to complete the causal path, the pressure needs to be heavy enough to trigger popular unrest or a potential regime change, or other factors that may threaten the dominant power (and even survival) of the leader group. However, existing literature notes that, under a strict and repressive authoritarian regime, political opposition can hardly develop. ${ }^{56}$ Indeed, while there is some evidence of internal anti-government activities, the social cohesion of the DPRK seems to have grown stronger. Through exploiting the foreign threat to control its own populace, the regime has demonstrated its ability to maintain a pro-regime mass consensus. ${ }^{57}$ It is hardly a surprise since similar situations also occurred in Iraq and the

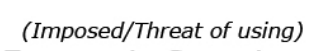

Fig. 9. Potential Causal Path: Triggering Regime Change.

Source: Created by author.

${ }^{53}$ Stephan Haggard, Marcus Noland, and Erik Weeks, "Markets and Famine in North Korea," Global Asia, Vol. 3, No. 2 (2010), p. 35.

${ }^{54}$ Beyond Parallel, "Meager Rations, Banned Markets, and Growing Anger Toward Government."

${ }^{55}$ Pembroke, "The Privileged Elite of North Korea Live A Charmed Life."

${ }^{56}$ De Jonge Oudraat, "Making Economic Sanctions Work."

${ }^{57}$ Bruce W. Bennett and Jennifer Lind, The Collapse of North Korea: A Prospect to Celebrate or Fear? (Johns Hopkins University, Applied Physics Laboratory, 2010). 
Federal Republic of Yugoslavia (FRY). During the sanctioning period, "Saddam remain[ed] in charge in Baghdad, and [did] not shelve plans to develop weapons of mass destruction," whereas in FRY the Serbs rallied around the flag and blamed the UN instead of Milosevic for their hardship. ${ }^{58}$ Therefore, rather than cause hardships on the target, economic sanctions largely validate the discourse of the ruling class. As argued by Hufbauer et al., "sanctions may create their own antidotes. In particular, economic sanctions may unify the target country in support of its government." ${ }^{59}$

The public distribution system under a centralized political system, alongside a high-level social unity, does not only ensure great resistance among North Koreans against economic sanctions, but it also undercuts the route through which "pressure" can lead to the change of policy (see Fig. 10). Meanwhile, since the people, instead of the policymakers, shoulder most of the pressure of economic sanctions, senders that expect more economic restraints to achieve policy concessions should realize that it is most probably done at the expense of ordinary North Koreans who constitute 90 percent of the population. Meanwhile, instead of arousing mass movements in opposition to their leader, economic sanctions are more likely to lead to a more united North Korea. After all, this country has experienced considerable hardships in the past; the pain threshold of North Koreans, particularly in face of external hostilities, is remarkably high.

From this perspective, a large-scale humanitarian crisis is foreseeable should the economic sanctions progress further. As De Jonge Oudraat

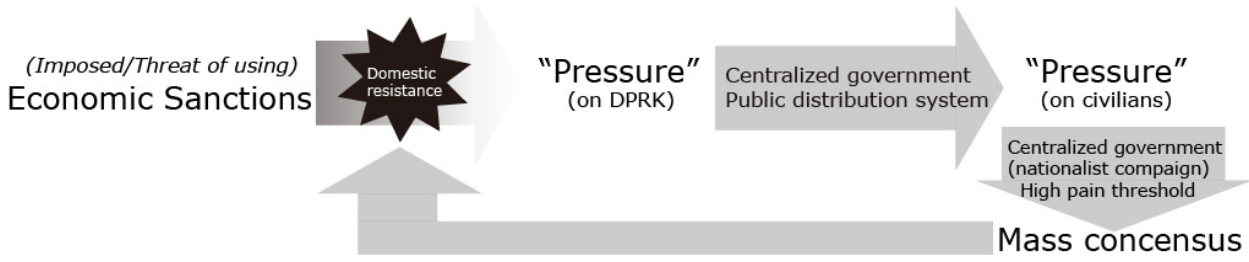

Fig. 10. Obstacle in Potential Causal Path: Centralized Public Distribution System. Source: Created by author.

${ }^{58}$ De Jonge Oudraat, “Making Economic Sanctions Work,” p. 108-109.

${ }^{59}$ Hufbauer et al., Economic Sanctions Reconsidered, p. 8. 
notes, when dealing with weak economies like North Korea, "comprehensive sanctions may easily lead to a humanitarian emergency." ${ }^{60}$ One should remember that "the famine of the mid-1990s was accompanied, or even triggered, by the collapse of a foreign trade structure, ${ }^{\prime 61}$ in which between 600,000 and 1 million people died. ${ }^{62}$ Even after the great famine, the development of nuclear- and ballistic missile-programs remained. Although recent data indicates that North Korea is nothing close to a food crisis $^{63}$ food insecurity has certainly posed a lasting challenge to North Korean society.

\section{Conclusion}

The Korean Peninsula has been called the "land of bad options," for numerous solutions have been sought out with little reward. ${ }^{64}$ Aiming at deterring North Korea's nuclear ambition, the multilateral and comprehensive sanction program, which is expected to "maximize general costs on target," ${ }^{\prime 65}$ has so far yielded little progress. Much to the senders' disappointment, even the maximum level of pressure seems unable to produce positive policy outcomes in the DPRK. Instead of being "the best policy option," ${ }^{\prime 66}$ economic sanctions have proven to be a futile policy instrument in promoting de-nuclearization in North Korea.

Applying the two-step working mechanism, this study identifies several notable obstacles in the potential causal pathways. First, the targets of economic deprivation were miscalculated before 2016. Although the

${ }^{60}$ De Jonge Oudraat, "Making Economic Sanctions Work," p. 118.

${ }^{61}$ Ruediger Frank, “North Korea's Foreign Trade," 38 North, October 22, 2015, http:// www.38north.org/2015/10/rfrank102215/.

${ }^{62}$ Haggard and Noland, Hard Target: Sanctions, Inducements, and the Case of North Korea.

${ }^{63}$ Benjamin Katzeff Silberstein, "Between Sanctions, Drought and Tensions: How Bad is North Korea's Food Situation?," 38 North, November 14, 2017, http://www.38north.org/2017/ 11/bksilberstein111417/.

${ }^{64}$ Ralph Cossa, "Dealing with the DPRK: Exploring the Trump Administration's Options," Center for Strategic and International Studies, December 1, 2016, https://www. csis.org/analysis/pacnet-87-dealing-dprk-exploring-trump-administrations-options.

${ }^{65}$ Abel Escribà-Folch, "Economic Sanctions and the Duration of Civil Conflicts," Journal of Peace Research, Vol. 47, No. 2 (2008), pp. 129-141.

${ }^{66}$ Ruggiero, "A Legislative Proposal to Impede North Korea's Access to Finance." 
senders, particularly the United States and EU, began to shift their focus to the whole economy afterwards, it remains difficult to implement. In part, the difficulty derives from the lack of knowledge of the domestic political economic structure, which makes it difficult to locate the precise target vis-à-vis North Korea's revenue. Meanwhile, it is also uncertain whether conventional economic sanctions can tackle unrevealed advanced funding capabilities that are rooted in the globalization process. Second, assuming that a well-aligned sanction regime can generate normative constraints and lead the target government into acquiescing is theoretically flawed, especially when there are conflicting interests and policy priorities among major senders. Collaboration on tougher sanctions against North Korea has been difficult to achieve. Third and most importantly, the two-step mechanism that covers multiple causal pathways proves to be impracticable for North Korea, due to the country's special social and political characteristics. An authoritarian political system, alongside strong social cohesion, not only breaks the path from pressure to policy change, but also forecasts the undesired policy outcome of economic sanctions in the case of North Korea.

Given these issues, what policies may be effective in bringing about denuclearization in North Korea? Under the current circumstance, lifting the sanction regime is certainly not feasible. One possible approach is to re-set current policy goals as different small steps, which requires a resetting of all expected causal pathways. As noted in the EU's sanction over Libya, "while giving up on [weapon of mass destruction] (WMD) by Libya was part of the deal, it was never put forward as a specific sanctions policy demand." ${ }^{\prime 67}$ Similar thinking may be useful for North Korea. The first small goal should be limited and not appear to contradict Pyongyang's current policy fundamentally. For instance, economic sanctions can serve to provide pressure for the setting up of informal or formal dialogues not directly aiming at denuclearization (at least in public announcements), but at searching for the next possible step toward de-nuclearization as well as collecting needed information. By opening up seemingly irrelevant dialogues, information can flow between North Korea and the international community, which may help sanctioning countries to identify unknown contributing factors as well as other potential solutions. Nevertheless, such an approach should be managed by the UN rather than individual countries; meanwhile, it should

${ }^{67}$ Gebert, Shooting in the Dark? EU Sanctions Policies. 
be accompanied by an enforceable consensus on which sanctions may be lifted if certain small policy goals are fulfilled.

Of course, if the senders insist on the current trend of imposing stricter comprehensive sanctions, the favorable policy outcome will remain open to speculation; the DPRK's policymakers might change their minds voluntarily for concerns of the regime survival under an eminent humanitarian crisis or undetected causal pathways not yet demonstrated in the past cases. However, as Robert Gallucci, chief U.S. negotiator with Pyongyang during the Bill Clinton administration, told the media, "during his contacts with DPRK officials, he realized they were fully aware of the cases of Iraq and Libya, where the U.S. pursued regime change even after those countries had abandoned their attempts to acquire nuclear weapons." ${ }^{68}$ Therefore, it seems that the option has been carefully scrutinized, and the costs clearly exceed the benefits for the officials. Besides, an unacceptable level of civilian suffering may very likely follow the policy concession.

To conclude, this study shows that the effectiveness of sanctions is largely subject to contexts of the target, senders and international community. In other words, treating economic sanctions as a "master key" in foreign policy is bound to fail. ${ }^{69}$ The case study on North Korea proves that economic sanctions are not universally applicable policy instruments. Therefore, any imposition of sanctions requires careful assessment of the potential relevant factors in the context of the specific country and global environment; otherwise, it is expected to face similar disappointing outcomes as shown in the case of North Korea.

68“US Helping None in DPRK Issue,"China Daily, September 4, 2017, http://www.chinadaily.com.cn/2017-09/04/content_31556410.htm.

${ }^{69}$ Richard N. Haass, "Economic Sanctions: Too Much of A Bad Thing," Brookings Institution, June 1, 1998, https://www.brookings.edu/research/economic-sanctions-toomuch-of-a-bad-thing/. 